\title{
The Recovery Strategy of Mangrove Tourism after Covid-19 Pandemic in Bintan Island, Indonesia
}

\author{
Khairunnisa Khairunnisa ${ }^{1}$, Tetty Tetty ${ }^{1}$, K Hafsar ${ }^{1}$, Haidawati Haidawati ${ }^{1}$, Wahyudin Wahyudin ${ }^{1}$, M P Suhana ${ }^{2}$,W \\ Muzammil $^{3}$, R D Putra ${ }^{4}$, Hanifah Hanifah ${ }^{5}$ \\ ${ }^{1}$ Social Economic Fisheries Department, Faculty of Marine Science and Fisheries, Raja Ali Haji Maritime University, Indonesia \\ ${ }^{2}$ Marine Science Department, Faculty of Marine Science and Fisheries, Raja Ali Haji Maritime University, Indonesia \\ ${ }^{3}$ Aquatic Resources Management Department, Faculty of Marine Science and Fisheries, Raja Ali Haji Maritime University, \\ Indonesia \\ ${ }^{4}$ Naval Architecture Department, Faculty of Engineering, Raja Ali Haji Maritime University, Indonesia \\ ${ }^{5}$ English Education Departement, Faculty of Teacher Training and Education, Raja Ali Haji Maritime University, Indonesia
}

\begin{abstract}
The Corona Virus Disease 2019 (Covid-19) has been confirmed as pandemic by the World Health Organization (WHO). Every country in the world is affected by this disease, including Indonesia. Covid-19 impacts not only public health but also other sectors such as tourism. This study aims to discover the solution to recover mangrove tourism after the pandemic. This study formulates the mangrove tourism recovery strategy after Covid-19 that conducted from April to August 2021 in Bintan Islands, Indonesia. The recovery strategy using Strength, Weakness, Opportunity, and Threat (SWOT) and Analytical Hierarchy Process (AHP) analysis. The result shows that the strength of mangrove tourism in Bintan Island is the magnificence of the mangrove itself, the communitybased tourism, various and unique tourism activities, etc. The weakness is incomplete facilities, lack of promotion, etc. The recovery strategy priority is mangrove tourism management that performed by BUMDes, Establishment of Pengudang Village Tourism and Cultural Heritage, Training and Mentoring of Mangrove Tourism Managers.
\end{abstract}

\section{Introduction}

The Coronavirus 2 Respiratory Syndrome or commonly known as Coronavirus Disease 2019 (Covid19) has been declared as pandemic by the World Health Organization [1]. Coronavirus is a zoonotic virus originated from Wuhan, China that breaks since December 2019. Every country in the world is affected by this disease, including Indonesia. Based on the latest data of WHO, Covid-19 cases in Indonesia in October 19, 2020 is the 19th highest in the world and the 1st in Southeast Asia. Covid-19 not only impact the public health around the world but also on other sectors; one of them is the tourism sector [2].

The Covid-19 pandemic has significant impact to world tourism. According to UNWTO during the first quarter of 2020 the international tourist arrival is decreased to $65 \%$. This number is unprecedented as every country restrict its borders and enforce travel warning in effort to minimize the virus transmission. The massive decline in tourist arrival resulted to the loss of 440 million potential international arrivals and approximately US\$ 460 billion potential revenues in tourism activity, equivalent to five times loss in international tourism revenues in 2009 financial and global economic crisis [3].

Tourism sector around Asia and Pacific regions is the most affected by this condition that result to the decline of tourist arrival to $72 \%$ over a six-month period3. The tourism decline is also happened in Indonesia with $89.22 \%$ of tourist arrival decline that being recorded from August 2019 to August 2020. One of the entrances for foreign tourist is through the Riau Islands. The decrease of tourist declines in Riau Islands is $99.92 \%$. This number is excessive considering that Riau Islands is one of the provinces in Indonesia that relies on tourism as a source of income [4].

Many tourism objects become tourist attraction in Riau Islands and mangrove is one of it. Mangrove provides many benefits to human welfare especially for the coastal communities [5][6][7][8][9]. Mangrove is tropical and subtropical ecosystem with high productivity which characterized by its important function and ecosystem as the central welfare for many coastal communities [10]. Mangrove has many social functions and tourist attraction hotspot is one of it [11]. Foreign tourists are mostly attracted by natural concept like mangrove tourism because is rarely found in their own countries. The declines of foreign tourist has a considerable impact to Bintan Island mangrove's community. Regarding to this issue it is necessary to conduct research related to the strategy of mangrove tourism to recover after Covid-19 outbreak especially in Bintan Island. The purpose of this study is to formulate a post-pandemic recovery strategy for mangrove tourism.

\section{Methods}

This research conducted from April 2021 to August 2021 located at mangrove tourism object of Bintan Island, namely Teluk Sebong District and Seri Kuala 
Lobam District, precisely in Sebong Lagoi Village, Pengudang Village, and Kuala Sempang Village (Figure 1). The data of this study is collected using several instruments those are questionnaires, in-depth interview, and Focus Group Discussion.

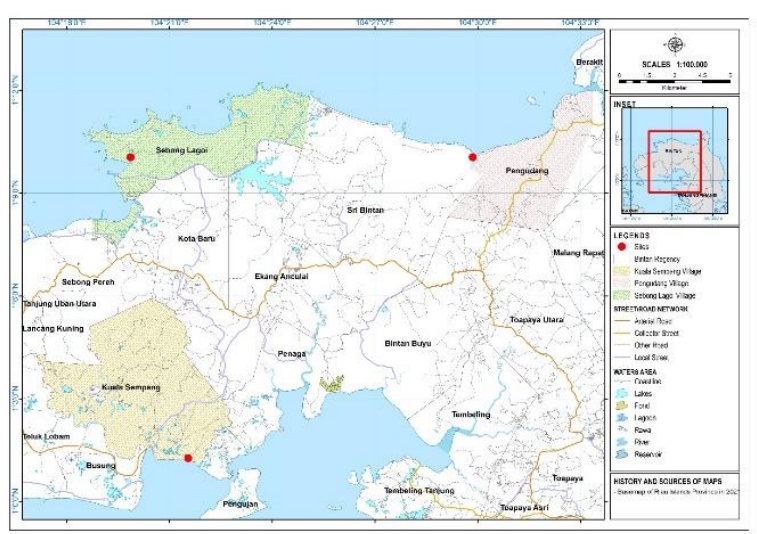

Figure 1. Sampling site.

\subsection{SWOT Analyses}

One of the analyses used to formulate the recovery strategy for mangrove tourism in Bintan Island is Strength, Weakness, Opportunity and Threats (SWOT). This analysis is used to determine the advantages, disadvantages, opportunities and obstacles obtained from the result of questionnaires, focus group discussion, and in-depth interview from informants and participants. The formulated result used in this research is SWOT analysis in form of strength opportunity, weakness opportunity, strength threat, and weakness threat concern on the ecotourism development strategy in Kemujan with the level of benefits and current condition [12]. SWOT analysis is also applied on the development strategy of Wonorejo mangrove ecotourism[13].

\subsection{AHP Analyses}

After formulating the recovery strategy using SWOT analyses then the priority is formulated using Analytical Hierarchy Process. It aims at facilitate the policies determination that must be prioritized in the mangrove tourism recovery strategy after pandemic-2019. It aims to facilitate the policy establishment that must be prioritized for the mangrove tourism recovery strategy after pandemic. The AHP analysis is based on weighting criteria method, where each criteria and sub-criteria weight value is input value based on the result of interview with the key person as competent authorities in determining the decision maker or policy [14]

\section{Result}

\subsection{Recovery Strategy}

\subsubsection{Sebong Lagoi Village}

Based on the analysis that has been conducted, there are six strategies for the mangrove tourism recovery in Sebong Lagoi Village (Table 1). The strategy consist of one SO Strategy, two WO Strategies, one ST strategy, and two WT strategies.

Table 1. Recovery Strategy of Mangrove Tourism at Sebong Lagoi Village

\begin{tabular}{|c|c|c|}
\hline Internal Factors & \begin{tabular}{ll} 
& \multicolumn{1}{c}{ Strengths (S) } \\
1. & Community based \\
mangrove tourism \\
2. Various and unique \\
tourism activities \\
3. Good services \\
4. The tour package \\
includes insurance \\
5. Beautiful mangrove \\
6. Skillful and experienced \\
tour guide
\end{tabular} & $\begin{array}{l}\quad \text { Weaknesses (W) } \\
\text { 1. Incomplete facilities (no port } \\
\text { and rest area). } \\
\text { 2. The environment surrounding } \\
\text { is not well maintained } \\
\text { 3. The promotion is not optimal } \\
\text { 4. There is no cooperation } \\
\text { between mangrove tourism } \\
\text { management and BUMDes. }\end{array}$ \\
\hline $\begin{array}{l}\text { Opportunies (O) } \\
\text { 1. Add other tourism } \\
\text { activities into } \\
\text { mangrove tour } \\
\text { packages. } \\
\text { 2. Provide excellent } \\
\text { service for visitors. }\end{array}$ & \begin{tabular}{l}
\multicolumn{1}{c}{ SO Strategy } \\
1. The synergy among \\
Tourism Management, \\
Community, Government \\
and Private sectors.
\end{tabular} & $\begin{array}{l}\text { WO Strategy } \\
\text { 1. Determination of Regulation } \\
\text { Related to Mangrove Tourism } \\
\text { Management. } \\
\text { 2. Mangrove Tourism Managers } \\
\text { is managed by BUMDes. }\end{array}$ \\
\hline \begin{tabular}{l}
\multicolumn{1}{c}{ Threats (T) } \\
1. Mangrove tourism is \\
less impactful to local \\
community's economy. \\
2. There is no rules for \\
managers of mangrove \\
tourism (especially \\
Environmental Impact \\
Assessment)
\end{tabular} & \begin{tabular}{ll}
\multicolumn{1}{c}{ ST Strategy } \\
1. Stakeholder Coordination \\
Regarding Environmental \\
Impact Assessment of \\
Mangrove Management
\end{tabular} & $\begin{array}{ll}\text { WT Strategy } \\
\text { 1. Tour Package Rebranding and } \\
\text { Promotion. } \\
\text { 2. Cooperate with Online Travel } \\
\text { Service Provider. }\end{array}$ \\
\hline
\end{tabular}

\subsubsection{Pengudang Villlage}

There are six strategies that have been successfully formulated for the mangrove tourism in Pengudang Village (Table 2), those are two SO strategies, two WO strategies, one ST strategy, and one WT strategy.

Table 2. Recovery Strategy of Mangrove Tourism at Pengudang Village

\begin{tabular}{|c|c|c|}
\hline Internal Factors & $\begin{array}{l}\quad \text { Strengths (S) } \\
\text { 1. Beautiful mangrove } \\
\text { 2. Various and unique tourism } \\
\text { activities } \\
\text { 3. Community based } \\
\text { mangrove tourism } \\
\text { 4. Close to the beach }\end{array}$ & $\begin{array}{l}\text { Weaknesses (W) } \\
\text { 1. Incomplete facilities (no } \\
\text { toilet, parking area, and } \\
\text { souvenir store). } \\
\text { 2. The beach is not properly } \\
\text { managed. } \\
\text { 3. There is no tourism center }\end{array}$ \\
\hline $\begin{array}{l}\text { Opportunies (O) } \\
\text { 1. The mangrove Tourism } \\
\text { Managers cooperates } \\
\text { with BUMDes. } \\
\text { 2. Known as a tourist } \\
\text { village. } \\
\text { 3. Centre of Education } \\
\text { and Conservation in } \\
\text { Bintan Regency. } \\
\text { 4. Collaborates with } \\
\text { university for research }\end{array}$ & \begin{tabular}{l}
\multicolumn{1}{c}{ SO Strategy } \\
1. The Synergy among \\
Government and \\
stakeholders \\
2. Increasing tourism \\
promotion
\end{tabular} & $\begin{array}{l}\text { WO Strategy } \\
\text { 1. Improve Facilities and } \\
\text { Infrastructure } \\
\text { 2. Improve Human } \\
\text { Resources in Tourism } \\
\text { Management }\end{array}$ \\
\hline $\begin{array}{l}\quad \text { Treaths (T) } \\
\text { 1. Oil spill waste } \\
\text { 2. No Government } \\
\text { supports } \\
\text { 3. All village land is } \\
\text { private property } \\
\text { 4. People are less aware of } \\
\text { tourism. }\end{array}$ & \begin{tabular}{l}
\multicolumn{1}{c}{ ST Strategy } \\
1. Increase public awareness \\
about mangrove tourism
\end{tabular} & $\begin{array}{l}\text { WT Strategy } \\
\text { 1. Establishment of } \\
\text { Pengudang Village } \\
\text { Tourism and Cultural } \\
\text { Heritage Center }\end{array}$ \\
\hline
\end{tabular}




\subsubsection{Kuala Sempang Village}

There are six strategies for mangrove tourism recovery in Kuala Sempang Village that have been formulated, those are two SO Strategy, one WO Strategy, two ST strategies, and one WT strategy (Table 3).

Table 3. Recovery Strategy of Mangrove Tourism at Kuala Sempang Village

\begin{tabular}{|c|c|c|}
\hline Internal Factors & $\begin{array}{l}\quad \text { Strengths (S) } \\
\text { 1. Beautiful mangrove } \\
\text { 2. Has business license from } \\
\text { the investment office } \\
\text { 3. Various and unique tourism } \\
\text { activities } \\
\text { 4. The tour package includes } \\
\text { insurance }\end{array}$ & $\begin{array}{l}\text { Weakness (W) } \\
\text { 1. Incomplete facilities (no } \\
\text { office, port, boat, and } \\
\text { lighting) } \\
\text { 2. The mangrove tourism is } \\
\text { individually managed } \\
\text { 3. The environment } \\
\text { surrounding is not well } \\
\text { maintained } \\
\text { 4. The promotion is not } \\
\text { optimal }\end{array}$ \\
\hline $\begin{array}{ll}\text { Opportunies }(\mathbf{O}) \\
\text { 1. } \\
\text { 2. } & \text { Colucationon center } \\
\text { seafood restaurants for } \\
\text { tour packages } \\
\text { 3. } \\
\text { Provide excellent } \\
\text { services for visitors. }\end{array}$ & \begin{tabular}{l}
\multicolumn{1}{c}{ SO Strategy } \\
1. Improvement of facilities \\
and infrastructure. \\
2. Collaborate with other \\
tourism managers and the \\
tourism office
\end{tabular} & \begin{tabular}{l}
\multicolumn{1}{c}{ WO Strategy } \\
1. Training and mentoring of \\
mangrove tourism \\
managers
\end{tabular} \\
\hline $\begin{array}{l}\text { Threaths (T) } \\
\text { 1. People are less aware of } \\
\text { tourism. } \\
\text { 2. Government policy } \\
\text { only focus on the } \\
\text { output, not the process. }\end{array}$ & \begin{tabular}{l}
\multicolumn{1}{c}{ ST Strategy } \\
1. Increase public awareness \\
about mangrove tourism \\
2. Development of mangrove \\
processing business
\end{tabular} & $\begin{array}{l}\quad \text { WT Strategy } \\
\text { 1. Tour Package Rebranding } \\
\text { and Promotion. }\end{array}$ \\
\hline
\end{tabular}

\subsubsection{Priority Strategy}

\section{Sebong Lagoi Village}

Priority strategy in Sebong Lagoi Village is shown in Figure 2. Among the six mangrove tourism recovery strategies have been formulated it is important to priorities which strategy is must be applied first. Priority strategy of this study is shown in Figure 2.

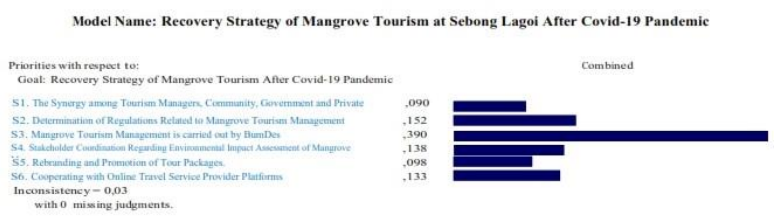

Figure 2. The Priority Strategy of Mangrove Tourism at Sebong Lagoi Village

Figure 2 shows the highest value is Mangrove tourism management carried out by BUMDes (0.390) while the lowest strategy value is the synergy among tourism management, community, government, and private sectors (0.090).

\section{Pengudang Village}

Based on the six strategies that have been formulated, it is necessary to determine the priority strategy to facilitate policy determination in efforts to recover mangrove tourism in Pengudang Village (Figure 3).

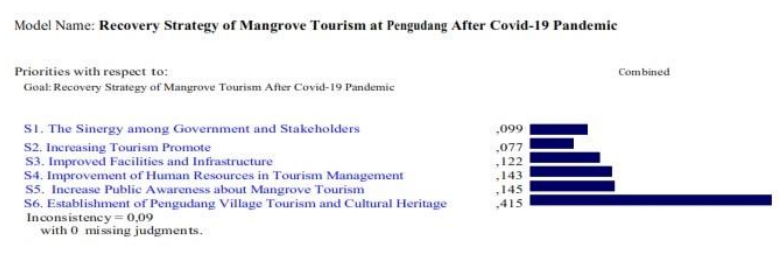

Figure 3. Priority Strategy of Mangrove Tourism at Pengudang Village

The figure above shows that the highest value is Establishment of Tourism Villages and Pengudang Cultural Heritage (0.415) and the lowest value is Increasing Tourism Promote (0.077).

\section{Kuala Sempang Village}

The priority strategy for mangrove tourism recovery in Kuala Sempang Village need to be formulated based on the six strategies that have been obtained. The priority of the strategy is presented in Figure 4.

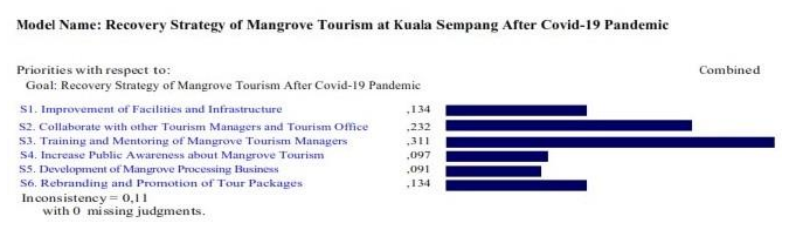

Figure 4. Priority Strategy of Mangrove Tourism at Kuala Sempang Village

Figure 4 shows that the strategy with the largest value is Training and Mentoring of Mangrove Tourism Managers (0.311) while the strategy with the smallest value is Development of Mangrove Processing Business (0.091).

\section{Discussion}

Natural disaster, pandemic, terrorism, and uprising are easy examples that might turn tourism business or industry become vulnerable. Therefore it is important to prepare the counter and recovery strategy for tourismrelated sectors [15]. In an particular insidence such as pandemic the tourism industry suffers extensively and this condition has worldwide impact. The over-reaction to pandemic is the main reason for the collapse of Asian tourism, according to previous studies in some studies, suggest that significantly affect global tourist demand[16][17]. The Covid-19 pandemic that has occured in the last two years has also had a considerable impact to mangrove tourism in Bintan Island. Based on the previous research, it is known that mangrove tourism in Bintan Island had not opened since March 2020 until now. This condition inflict a financial loss since many people lose their jobs and source of income. In addition it also causes the damaged of mangrove tourism infrastructure because it has not been used for a long time.

Since the first half of 2021 the whole world has been trying to recover from the Covid-19 pandemic. Indonesia itself implements the Large-Scale Social Restriction (PSBB) policy and is aggressively implementing vaccines as an effort to recover from the pandemic. The same effort also needed to recover the 
tourism sector. The economy condition which has gradually recovered will be accompanied by the return of people's interest to travel. The recovery strategy for mangrove tourism in Bintan Island was obtained based on SWOT and AHP analysis.

The research use SWOT analysis showed the effective strategy for the ecotourism area development as an aggressive strategy [13]. In Sebong Lagoi Village, there are six strategies that can be applied as an effort to recover mangrove tourism after the Covid-19 pandemic. These strategies are the management of mangrove tourism carried out by BUMDes (0.390), the establishment of regulation related to mangrove tourism management (0.153), coordination of stakeholders related to the analysis of the environmental impact of mangrove (0.138), collaboration with online travel service provider (0.133), tourism package rebranding and promotion(0.098), as well as the synergy between tourism managers, the community, the government, and the private sector (0.090).

All of the strategies are required to recover the mangrove tourism in Sebong Lagoi Village quickly. However, the strategy that need to be on the top priority is the management of mangrove tourism carried out by BUMDes. Today the management of mangrove tourism in Sebong Lagoi Village is handled individually cause its existence is not optimal and less impactful on local communities both economically and socially. Moreover, it is harder to deal with the crisis during the Covid-19 pandemic. The management of mangrove tourism by BUMDes can be applied as an effort to recover the mangrove tourism in Sebong Lagoi Village.

Wonorejo mangrove ecotourism has a development strategy by using a top-down and bottom-up model. This strategy requires sustainable management and an integrated policy. Both of the models are done holistically with a cooperation among stakeholders in order to raise an awareness stakeholder communities to protect their environment [13]. There are six strategies that can be applied as an effort to recover mangrove tourism after the Covid-19 pandemic in Pengudang Village. The strategies are Increasing tourism promotion (0.077), the synergy among government and stakeholders (0.099), improved facilities and infrastructure $(0,122)$, improvement in human resources in tourism managements (0.143), increase public awareness about mangrove tourism (0.145), and Establishment of Pengudang Village Tourism and Cultural Heritage (0.415). The top priority strategy among others is the Establishment of Pengudang Village Tourism and Cultural Heritage.

Most of the land in Pengudang Village is privately owned so almost all villagers borrow land for their homes, village administrative and mangrove tourism areas. Based on the results of Focus group discussion the best solution related to the problem is establishing Pengudang Village as a tourism village and cultural heritage. By executing this solution, the villager will get the land ownership and other recovery strategies can be applied. Based on the result of stakeholders interviews with AHP analysis obtained the top priority in the management of marine mina-tourism based on mangrove coastal area, the results is: (a) Management of marine biological resources and coastal area in order to improve coastal community welfare through tourism and fisheries, weight 0.4428 ; (b) cooperation management in order to improve the quality of human resources through community empowerment development and provide strategic infrastructure, weigh 0.3218; and (c) cooperation management within the conservation, marine and fisheries resource protection, weight $0.2355[14]$.

The strategy to recover the mangrove tourism after the Covid-19 pandemic in Kuala Sempang Village consists of six strategies. The strategies are Training and Mentoring of Mangrove Tourism Managers (0.311), collaborate with other tourism managers and tourism office (0.232), improved facilities and infrastructure (0.134), tour package rebranding and promotion (0.134), increasing public awareness about mangrove tourism (0.097), and development of mangrove cultivation business (0.091). All of these strategies are intended as an effort to restore mangrove tourism in Kuala Sempang Village after the COVID-19 pandemic.

However, the priority strategy is Training and Mentoring of Mangrove Tourism Managers. Mangrove tourism in Kuala Sempang Village is the newest mangrove tourism object among other samples in this study. The mangrove tourism was established in 2019 no longer before Covid-19 break out so it cannot operate until now. In order to recover the mangrove tourism in Kuala Sempang Village, it is necessary to give the manager training and assistance for preparing and developing the mangrove tourism better. The result of development of mangrove ecotourism study in Kakaralamo is to formulate strategy to improve the quality of human resources and manage the potential of mangrove ecotourism in that area [6].

\section{Conclusion}

The mangrove tourism in Bintan island that collapsed by Covid-19 pandemic needs to be recovered immediately, considering that countries in the world are improving to rise from prolapse in many sectors including the tourism. There are 6 strategies of each samples that can be considered in the recovery of Bintan Island after the Covid-19 pandemic end. There are three main priorities from all of the strategies, (1) Mangrove tourism management is carried out by BUMDes, value 0.390 ; (2) Establishment of the Pengudang Village Tourism and Cultural Conservation Village, value 0.415; (3) Training and Assistance for Mangrove Tourism Managers, value 0.311 . The third main strategy can be the first to realize for mangrove tourism in Bintan Island after the Covid-9 pandemic. Following with supporting strategies that can be applied each. The final priority strategies are (1) the synergy between tourism management, the community, the government, and the private sector, value 0.90 ; (2) Increasing Tourism Promotion, value 0.77; and (3) Development of Mangrove Processing Business, value 0.91. 


\section{Acknowledgment}

The authors would like to thanks to UMRAH through LP3M which has supported funding in this research. And thanks to the mangrove tourism managers in Bintan Island and all those who helped in carrying out this research.

\section{References}

1. World Health Organization (WHO). Global Surveillance for Human Infection with Novel Coronavirus (2019-ncov). https://www.who.inthttps//www.who.int (2020).

2. World Health Organization (WHO). WHO Coronavirus Disease (COVID-19) Dashboard. https://covid19.who.int/table (2020).

3. World Tourism Organization (UNWTO). International Tourist Numbers Down $65 \%$ in Half of 2020, UNWTO Reports. https://www.unwto.org/news/international-touristnumbers-down-65-in-first-half-of-2020-unwtoreports (2020).

4. Kementerian Pariwisata dan Ekonomi Kreatif (KEMENPAREKRAF). Data Kunjungan Wisatawan Bulanan Tahun 2020. 2020 https://www.kemenparekraf.go.id/post/datakunjungan-wisatawan-mancanegara-bulanantahun-2020.

5. Tanner, M. K. et al. Mangroves in the Galapagos: Ecosystem services and their valuation. Ecol. Econ. 160, 12-24 (2019).

6. Arkwright, D. \& Kaomaneng, I. S. Mangrove Ecotourism Development on Kakaralamo Island North Halmahera: Community perception, participation and development strategies. IOP Conf. Ser. Earth Environ. Sci. 175, (2018).

7. Barbier EB et al. The value of estuarine and coastal ecosystem services. Ecol. Monogr. 81(2), 169-193 (2011).

8. M. Brander, L. et al. Ecosystem service values for mangroves in Southeast Asia: A meta-analysis and value transfer application. Ecosyst. Serv. 1, 62-69 (2012).

9. Himes-Cornell, A., Pendleton, L. \& Atiyah, P. Valuing ecosystem services from blue forests: A systematic review of the valuation of salt marshes, sea grass beds and mangrove forests. Ecosyst. Serv. 30, 36-48 (2018).

10. McNally, C. G., Uchida, E. \& Gold, A. J. The effect of a protected area on the tradeoffs between shortrun and long-run benefits from mangrove ecosystems. Proc. Natl. Acad. Sci. U. S. A. 108, 13945-13950 (2011).

11. Tuwo, A. Pengelolaan ekowisata pesisir dan laut: pendekatan ekologi, sosial-ekonomi, kelembagaan, dan sarana wilayah. (Brilian internasional, 2011).

12. Simanjuntak, S. W., Suryanto, A. \& Wijayanto, D. Strategi Pengembangan Pariwisata Mangrove di Pulau Kemujan, Karimunjawa. Diponegoro J. Maquares 4, 25-34 (2015).

13. Murtini, S., Sumarmi, Astina, I. K. \& Utomo, D. H.
SWOT Analysis for the Development Strategy of Mangrove Ecotourism in Wonorejo, Indonesia. Mediterr. J. Soc. Sci. 9, 129-138 (2018).

14. Umilia, E. \& Asbar. Formulation of Mangrove Ecosystem Management Model Based on Ecominawisata in the Coastal Sinjai, South Sulawesi. Procedia - Soc. Behav. Sci. 227, 704-711 (2016).

15. Yeh, S. S. Tourism recovery strategy against COVID-19 pandemic. Tour. Recreat. Res. 46, 188194 (2021).

16. Kuo, H. I., Chen, C. C., Tseng, W. C., Ju, L. F. \& Huang, B. W. Assessing impacts of SARS and Avian Flu on international tourism demand to Asia. Tour. Manag. 29, 917-928 (2008).

17. Mckercher, B. \& Chon, K. The Over-Reaction to SARS and the Collapse of Asian Tourism. Ann. Tour. Res. 31, 716-719 (2004). 